\title{
Unilateral proptosis in a woman with asthma
}

\author{
Saori Sakaue, Shuji Sumitomo, Keishi Fujio, Kazuhiko Yamamoto
}

Department of Allergy and Rheumatology, The University of Tokyo Hospital, Bunkyo-ku, Tokyo, Japan

\section{Correspondence to} Dr Shuji Sumitomo, sumitos-tky@umin.ac.jp

Accepted 26 January 2015

\section{DESCRIPTION}

A 47-year-old woman with a history of bronchial asthma presented with progressive proptosis of the right eye and diplopia. Her right eye showed apparent exophthalmos, impaired movement, conjunctival hyperaemia and episcleritis. Laboratory analysis revealed an increased titre of MPO-ANCA $(4.3 \mathrm{IU} / \mathrm{mL})$ and hypereosinophilia $(1900$ cells $/ \mu \mathrm{L}$, $22.5 \%$ on white cell count). MRI showed significant swelling of the extraocular muscles of the right eye and right ethmoid sinusitis (figure 1). Since a biopsy of extraocular muscles is unfeasible due to a risk of complications, the right bulbar conjuctiva was biopsied and dense infiltration of eosinophils with a granuloma formation (figure 2, arrows) was found. There were several phagocytised Charcot-Leyden crystals (figure 2, arrowheads) that were created by the destruction of eosinophils and release of their inner granules. The patient was diagnosed with eosinophilic granulomatosis with polyangiitis (EGPA) based on this histology, along with asthma, sinusitis and eosinophilia. It was speculated that unilateral proptosis was caused by the eosinophilic orbital myositis. Thirty milligrams of prednisone dramatically improved her proptosis and conjunctivitis.

Orbital myositis is an inflammatory process that involves the extraocular muscles. The typical symptoms are orbital pain, ocular movement impairment, diplopia and proptosis. ${ }^{1}$ Orbital myositis is mainly idiopathic but sometimes caused by infection, thyroid dysfunction or systemic inflammatory diseases including antineutrophil cytoplasmic antibody-associated vasculitis. ${ }^{2}$ However, the

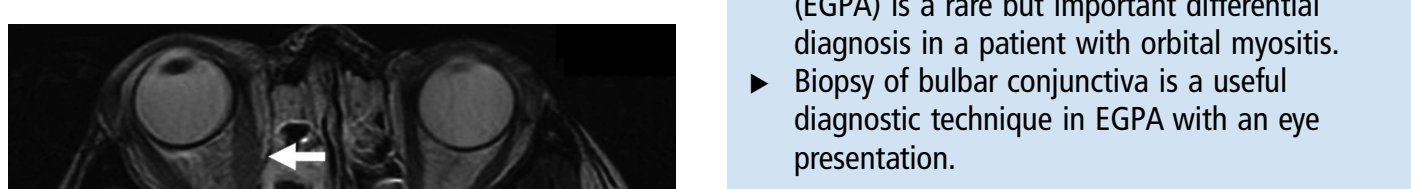

Contributors SSa and SSu wrote the manuscript and provided the figures. $\mathrm{KF}$ and $\mathrm{KY}$ supervised the manuscript.

Competing interests None.

Patient consent Obtained.

Provenance and peer review Not commissioned; externally peer reviewed.

\section{REFERENCES}

1 Yuen SJ, Rubin PA. Idiopathic orbital inflammation: distribution, clinical features, and treatment outcome. Arch Ophthalmol 2003;121:491-9.

2 Schmidt J, Pulido JS, Matteson EL. Ocular manifestations of systemic disease: antineutrophil cytoplasmic antibody-associated vasculitis. Curr Opin Ophthalmol 2011;22:489-95.

Figure 1 MRI showing swollen extraocular muscles of the right eye.
3 Gordon LK. Orbital inflammatory disease: a diagnostic and therapeutic challenge. Eye 2006;20:1196-206. 
Copyright 2015 BMJ Publishing Group. All rights reserved. For permission to reuse any of this content visit http://group.bmj.com/group/rights-licensing/permissions.

BMJ Case Report Fellows may re-use this article for personal use and teaching without any further permission.

Become a Fellow of BMJ Case Reports today and you can:

- Submit as many cases as you like

- Enjoy fast sympathetic peer review and rapid publication of accepted articles

- Access all the published articles

- Re-use any of the published material for personal use and teaching without further permission

For information on Institutional Fellowships contact consortiasales@bmjgroup.com

Visit casereports.bmj.com for more articles like this and to become a Fellow 